\title{
EXPLORATION OF ISLAMIC VALUES IN ISLAMIC BANKING (STUDY OF ISLAMIC BANK CUSTOMER PERSPECTIVE IN MAKASSAR)
}

\author{
Irwan Misbach* \\ Department of Dakwah Management, UIN Alauddin Makassar
}

\begin{abstract}
This study explores Islamic values in the operations of Islamic banks based on the perspective of customers in Makassar City. Based on factor analysis, 4 factors are found. Factor 1 contains "Islamic Products" which are "Amanah". Factor 2 contains "Islamic Performance" which is Tabliqh. Factor 3 contains "reliability or Islamic Assurance" that is identical to Sidiq. Factor 4 contains "Islamic services" that are identical to Fathanah. This research is able to form Islamic Corporate Governance indicators that respond to research challenges about the initial concept of islamic-corporate-governance implementation in Islamic banks through mandate in their products, tabliq in providing guarantees to customers, shiddiq which is reliability like syariah, and fathanah in serving customers in banking transaction.
\end{abstract}

Keywords: Customer Perspective, Islamic Bank, Islamic Value

* Corresponding author email: irwan.misbach@uin-alauddin.ac.id DOI: $10.24252 / \mathrm{minds.v6i1.7979}$

ISSN-E: 2597-6990 


\section{Introduction}

The existence of Islamic banking is to provide a variety of financial services that are acceptable to the Muslim community. Besides having specificpurpose just like the other aspects of Islamic society, it is expected to be able to contribute to the achievement of the main socio-economic goals of Islam (Chapra, 1985 in Hassan and Lewis, 2007: 2). Islamic banking business activities refer to Amar Ma'ruf Nahi Munkar. Makruf is a good deed that makes human calm, and munkar is an activity that avoids humans from evil, is forbidden and hated by the Shari'a (Munzir, 2016).

This is further confirmed in Article 2 of Law No. 21 of 2008 which states that Sharia Banking in carrying out its business activities is based on Sharia Principles. Sharia principles are business activities based on Sharia Principles, namely business activities that do not contain elements of usury, maisir, gharar, haram, and zalim. According to Muhammad (2008), the element of literacy in Islamic banking is to provide peace in business because one of the contracts is in the form of syirkah (cooperation), fairness, Islamic products and profit sharing ratio.

However, according to the Financial Service Authority (FSA/OJK) in the 2015-2019 Indonesian Islamic bank roadmaps, it revealed that the challenges of the development of Islamic banks, besides the weakness of human resources both in quantity and quality in Islamic banks, are alsoinlcuding Islamic banking products and services that have not met the customer expectations. In other words, the expectations of sharia bank customers are that Islamic banks operate based on sharia principles are Islamic values stated in the Koran and al-Hadith (Islamic Banking Department, 2015). Islamic values which are sharia principles in Islamic banking are a reference in the operational management of Islamic banks. This is where the role of these values in maintaining the operational pace, this value also distinguishes it from conventional banking. The use of the principles of sharia will make Muslims who are the customers of Islamic banks may be more at ease as economic actors, although it is possible that a sharia bank does not really use the implementation of sharia law.

It appears that the government has provided enough space for the development of Islamic banking in Indonesia Banking through Law No. 10 of 1998 and Law No. 21 of 2008 and strengthened by the existence of Islamic banking in Indonesia. Philosophically, Islamic banks are banks whose activities leave usury problems, and the practical reason is that interest-based or conventional banking systems contain weaknesses (Misbach, 2013). The facts show that the market share of Islamic banking in Indonesia is still below 5\% of total industrial assets (Widigdo, Marimin, Fahmi, and Beik, 2016), after more than two decades of operations in Indonesia. Since the establishment of the first Islamic bank in the 1990s, the Financial Services Authority (OJK) noted that Islamic banking increased significantly for $66.21 \%$ or 13 Public Islamic banks, $31.30 \%$ or 21 sharia business unit and $2.49 \%$ or as many as 167 Sharia Rural Banks in 2017 (OJK, 2018). 
According to the OJK (2015) at the International conference on Islamic finance in Jakarta, revealed that the existence of Islamic banks in Indonesia provides a variety of services and bank instruments. In addition, Islamic banks are able to create financial system stability and money markets, and contribute to supporting financial inclusion in Indonesia. Islamic banking market share until 2017 only reached $5.78 \%$ of the total national banking industry (OJK, 2017).

It is undeniable that Islamic banking is a subsystem of the Islamic economic system holistically is the knowledge and application of sharia commands and rules (Islamic law) that prevent injustice in obtaining and channeling material resources to give satisfaction to humans and enable them to perform their obligations to Allah and the community (Marifa Tim. 2014).

Rivai and Usman (2012), argue that economic fiqh (figh al-iqtișād) in Islam provides rules or guidelines about people's choices to meet their needs from available resources. These rules are obtained from ijtihāalbased on divine revelation, namely the Qur'an and hadith. He further stated that the values adopted in Islamic banks must be in line with the Islamic economic values. In addition to this, this research is also based on the statement of Muhammad ArifinBaderi in his book 'Riba and Critical Review of Islamic Banking' (2016), which states that there are still banks that have not fully implemented Islamic values which constitute sharia principles.

There must be an implementation of the Sharī'ah values in Islamic banks throughout their operations (Widigdo et al., 2016), and must promote these values to staff, customers and society in general (Dusuki, 2008). Some indicators of these norms or values consist of, but are not limited to, the following: commitment to always look for things that are legitimate (haläl) and good things (tayyib), avoid activities that are prohibited, avoid wasteful lifestyles, avoid oppressive activities, avoid elements of ribā, gharar and maysir, commitment to always uphold social responsibility such as zakäh, infäq, sadaqah, and the principles of justice and brotherhood (Antonio, 2001).

Sholihin (2010) classifies the five principles of Sharīah which must be followed in Islamic transactions. These principles are: brotherhood, justice, benefit, balance and universalism. Rivai and Usman (2012) describe that the principles of business ethics in Islam, such as tawhīd, khiläfah, worship ('ibädah), purification (tazkiyah) and ihsann, can be further classified under the general principles of justice, honesty, transparency, togetherness, freedom, responsibility and accountability. Brotherhood is the main principle that must be applied in the Sharī ah transaction. This must be reflected in Islamic banking operations where all parties involved must follow the steps of brotherhood, namely to get acquainted (ta äruf), to understand each other (tafähum), to help each other (ta'äwun), to guarantee each other (tadāmun), and to develop synergies, alliances and strong collaboration (tahāluf). 
The maslahah principle contains a deep understanding that all economic transactions must be able to produce multidimensional benefits that cover the dimensions of the world and the realm, the material and spiritual dimensions, as well as the individual and collective dimensions. It must fulfill halāl and tayyib requirements. The first related to the appropriate aspects of the Shari'a while the second brings goodness and blessing to all parties involved in the transaction (Sholihin, 2010). The Mașlahah transaction will be in line with maqūsid al-Sharī'ah which is the goal of Sharī'ah. According to Rivai and Usman (2012), the readiness of business practitioners to give goodness to others is the essence of the meaning of mașlahah based on the value of ihsān. This is in accordance with sūrah al-Naḥl (16: 90) and sūrah al-Qașaș (28: 77).

\section{Research Method}

This research design is quantitative approach. Quantitative approach is a research approach that works with numbers, data in the form of numbers (score or value, rank or frequency), analyzed using statistics to answer specific research questions or hypotheses, and to predict that a particular variable affects other variables (Creswell, 2002). Due to the very large population, the method becomes very sensitive so it is difficult to get good goodness of fit measures. The number of samples taken refers to the opinion of Hair et al (1995) which states that the number of samples taken should not be too large or not too small. Because the number of population in this study is not known with certainty, the non-sampling probability is used. Based on the accidental sampling method, the sample used was 105 respondents, and in accordance with the minimum number of respondents suggested by Solimun (2002).

Data analysis in the study used factor analysis. Factor analysis is used to reduce data or summarize many variables into fewer variables (Supranto, 2004: 117). It can be said that factor analysis is an analytical model that is useful in reducing information from a number of original variables to a simpler form of factors by minimizing lost information.In factor analysis, large numbers of variables are divided into a group of a number of factors that have almost the same characteristics and it will make it easier to process. Grouping is done by measuring the correlation of a set of variables and then placing variables that are highly correlated in one factor, and other variables that have a relatively lower correlation are placed on other factors. In this study, the factor analysis approach used was Exploratory Factor Analysis (EFA). EFA is a detailed model that shows the relationship between latent variables and observed variables that are not specified first.

\section{Results}

In analyzing the results of research on the exploration of Islamic values in Islamic banking in the perspective of the customer using factor analysis to identify variables/items based on their similarity, the similarity is indicated by a high correlation value. Variables that have a high correlation will form a 
crowd of factors. This factor analysis is known as the empirical extract and latent construct. 31 variables in this study are empirical extracts because they are obtained directly from the empirical scores. Factors are latent constructs because there are no empirical data that show the magnitude of these factors. Factors are extracts made by researchers based on the variables in these factors. Because factors are obtained from a set of variables that have a high intercorrelation, the researcher must then rationalize the set of variables and then label them to describe a set of these variables.

a. Assumption Analysis Factor Test

Factor analysis requires fulfilling a set of assumptions. The researcher tested the assumption of factor analysis before the factor analysis test was carried out. The independent variable correlation, in factor analysis, must be greater than 0.5 with a significance smaller than 0.05. The results of the correlation test between independent variables are at the KMO and Bartlett's Test output, as follows:

Table 1 KMO and Bartlett's Test

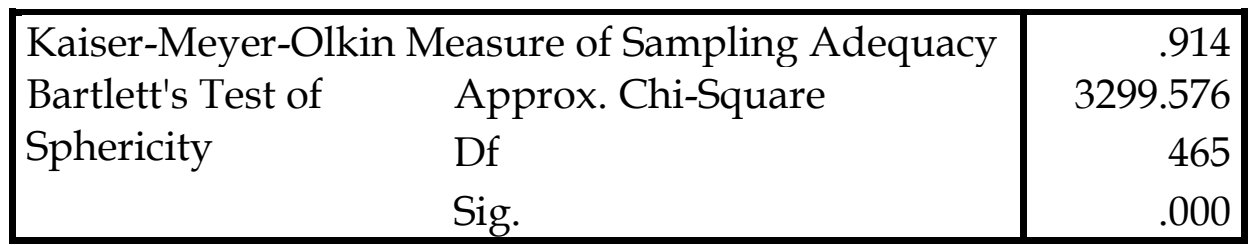

Source: Analyzed Data, 2018

The KMO and Bartlett's Test values for the correlation between the desired variables are $>0.5$. The significance of the study is 0.05 . From the results above obtained KMO value of 0.914 which means greater than 0.5. Meanwhile, the significance produced by Bartlett's Test of Sphericity is 0,000. (Santoso, 2006: 22) The results, it can be said that the variables and samples used allow further analysis. Furthermore, to see the correlation between independent variables, we can note the Anti-Image Matrices table. The value considered is MSA (Measure of Sampling Adequacy). The value of MSA ranges from 0 to 1 , with the following conditions (Santoso, 2006: 20):

MSA $=1$, variables can be predicted without errors by other variables.

MSA $>0.5$, variables can still be predicted and can be analyzed further.

MSA $<0.5$, variables cannot be predicted and cannot be analyzed further, or excluded from other variables.

Based on the results of the MSA above, all independent variables can be further analyzed because of each of their values $>0,5$.

b. Grouping Factor

The analysis factor determines independent variables can be divided into one or several factors (grouping factors). There are 31 independent variables in this study that is simplified into just a few factors (latent constructs).

Before grouping factors, these variables need to be explained how much of the factors that are formed later can explain the variables. For this reason, we must see the Communalities table as follows: (Santoso, 2006: 41) 
Table 2 Explain the variables

\begin{tabular}{|l|r|r|r|}
\hline Variable & Initial & Extraction & $\begin{array}{c}\text { Explain the } \\
\text { variables }\end{array}$ \\
\hline Harmonious interaction & 1.000 & .591 & $59,1 \%$ \\
Profit Sharing & 1.000 & .778 & $77,8 \%$ \\
Profit Agreement & 1.000 & .707 & $70,7 \%$ \\
Economic Development & 1.000 & .671 & $67,1 \%$ \\
Customer as a Partner & 1.000 & .650 & $65,10 \%$ \\
Balanced Profit & 1.000 & .844 & $84,4 \%$ \\
Balanced Risk & 1.000 & .782 & $78,2 \%$ \\
Not Differentiating Customers & 1.000 & .786 & $78,6 \%$ \\
Can be trusted & 1.000 & .836 & $83,6 \%$ \\
Accurate Information & 1.000 & .785 & $78,5 \%$ \\
Family & 1.000 & .723 & $72,3 \%$ \\
Freedom & 1.000 & .684 & $68,4 \%$ \\
Risk Minimization & 1.000 & .736 & $73,6 \%$ \\
Avoid Money Laundering & 1.000 & .697 & $69,7 \%$ \\
Successful Implementation of & 1.000 & .664 & $66,4 \%$ \\
Principles & 1.000 & .728 & $72,8 \%$ \\
Avoid Unauthorized Income & 1.000 & .764 & $76,4 \%$ \\
Transactions are not speculated & 1.000 & .774 & $77,4 \%$ \\
Clear contract & 1.000 & .677 & $67,7 \%$ \\
Willingness in Covenant & 1.000 & .603 & $60,3 \%$ \\
Do not conduct Haram Transactions & 1.000 & .759 & $75,9 \%$ \\
Investment Guarantee & 1.000 & .698 & $69,8 \%$ \\
Avoid Unfair Transactions & 1.000 & .800 & $80,0 \%$ \\
Legal Benefits & 1.000 & .707 & $70,7 \%$ \\
Based on Islamic principles & 1.000 & .693 & $69,3 \%$ \\
No Interest on Deposits & 1.000 & .784 & $78,4 \%$ \\
Islamic nuance & 1.000 & .714 & $71,4 \%$ \\
No Loan Interest & 1.000 & .637 & $63,7 \%$ \\
Profit Sharing Investment & 1.000 & .730 & $73,0 \%$ \\
Customer Partner & 1.000 & .683 & $68,3 \%$ \\
Proportion of Profit Sharing & 1.000 & .733 & $73,3 \%$ \\
Social Responsibility Commitment & & \\
\hline
\end{tabular}

Extraction Method: Principal Component Analysis.

Based on the results of Table 2 above, it can be said that the factor is able to explain the variable because all variables in the study are above $50 \%$, so the fixed factor will be determined. Furthermore, this analysis is carried out by determining the factors that might be formed. To determine how many factors might be formed can be seen in the table Total Variance Explained below (Santoso, 2006: 42). 
Table 3 Total Variance Explained

\begin{tabular}{|c|c|c|c|c|c|c|}
\hline \multirow[b]{2}{*}{$\begin{array}{l}\text { Compone } \\
\text { nt }\end{array}$} & \multicolumn{3}{|c|}{ Initial Eigenvalues } & \multicolumn{3}{|c|}{$\begin{array}{l}\text { Extraction Sums of Squared } \\
\text { Loadings }\end{array}$} \\
\hline & Total & $\begin{array}{c}\% \text { of } \\
\text { Variance }\end{array}$ & $\begin{array}{c}\text { Cumulative } \\
\%\end{array}$ & Total & $\begin{array}{c}\% \text { of } \\
\text { Variance }\end{array}$ & $\begin{array}{c}\text { Cumulative } \\
\%\end{array}$ \\
\hline 1 & 18.138 & 58.509 & 58.509 & 18.138 & 58.509 & 58.509 \\
\hline 2 & 1.927 & 6.216 & 64.725 & 1.927 & 6.216 & 64.725 \\
\hline 3 & 1.296 & 4.181 & 68.906 & 1.296 & 4.181 & 68.906 \\
\hline 4 & 1.058 & 3.412 & 72.318 & 1.058 & 3.412 & 72.318 \\
\hline 5 & .887 & 2.860 & 75.178 & & & \\
\hline 6 & .743 & 2.398 & 77.576 & & & \\
\hline 7 & .679 & 2.191 & 79.767 & & & \\
\hline 8 & .654 & 2.110 & 81.877 & & & \\
\hline 9 & .573 & 1.848 & 83.724 & & & \\
\hline 10 & .550 & 1.773 & 85.497 & & & \\
\hline 11 & .479 & 1.546 & 87.043 & & & \\
\hline 12 & .458 & 1.478 & 88.522 & & & \\
\hline 13 & .400 & 1.289 & 89.811 & & & \\
\hline 14 & .343 & 1.108 & 90.919 & & & \\
\hline 15 & .323 & 1.042 & 91.960 & & & \\
\hline 16 & .302 & .973 & 92.934 & & & \\
\hline 17 & .279 & .899 & 93.833 & & & \\
\hline 18 & .250 & .806 & 94.639 & & & \\
\hline 19 & .235 & .758 & 95.397 & & & \\
\hline 20 & .228 & .735 & 96.132 & & & \\
\hline 21 & .210 & .678 & 96.811 & & & \\
\hline 22 & .158 & .511 & 97.322 & & & \\
\hline 23 & .148 & .478 & 97.800 & & & \\
\hline 24 & .135 & .435 & 98.235 & & & \\
\hline 25 & .122 & .394 & 98.628 & & & \\
\hline 26 & .114 & .368 & 98.997 & & & \\
\hline 27 & .083 & .269 & 99.266 & & & \\
\hline 28 & .070 & .225 & 99.491 & & & \\
\hline 29 & .064 & .205 & 99.696 & & & \\
\hline 30 & .051 & .164 & 99.860 & & & \\
\hline 31 & .043 & .140 & 100.000 & & & \\
\hline
\end{tabular}

Extraction Method: Principal Component Analysis.

Source: Analyzed Data, 2018

Based on Table 3 above, it explains the components 1 to 31 which represent the number of variables of Islamic values in this study. The results of initial eigenvalues find 4 factors that exceed the total value 1 . This indicates that the 31 variables mentioned above will be grouped into 4 factors (latent 
constructs). The variance can be explained by factor 1 which is $18.138 / 31 \mathrm{x}$ $100 \%=58.51 \%$ and Factor 2 is $1.927 / 31 \times 100 \%=6.21 \%$. Furthermore, the variance that can be explained by Factor 3 is 1,296/31 $\times 100 \%=4.18 \%$ and factor 4 is $1.058 / 31 \times 100 \%=3.41 \%$. Thus the total of these four factors will explain the variable of $58.51 \%+6.21 \%+4.18 \%+3.41 \%=72.31 \%$. After knowing that the maximum factor that can be formed is 4, then determining the correlation of each independent variable will be in the factor 1 , factor 2 , factor 3 or factor 4 . The Component Matrix table shows the way to determine it: (Santoso, 2006: 45)

\section{Table 4 Component Matrix ${ }^{a}$}

\begin{tabular}{|l|r|r|r|r|}
\hline \multirow{2}{*}{} & \multicolumn{3}{|c|}{ Component } \\
\cline { 2 - 5 } & 1 & 2 & \multicolumn{1}{|c|}{3} & 4 \\
\hline Legal Benefits & .875 & -.181 & & \\
Risk Minimization & .839 & .103 & & .140 \\
Clear contract & .837 & & & -.259 \\
Investment Guarantee & .826 & -.208 & -.147 & -.106 \\
Transactions are not speculated & .822 & -.261 & -.142 & \\
Willingness in Covenant & .819 & & & \\
Accurate Information & .816 & & -.162 & -.304 \\
Islamic nuance & .814 & -.204 & .263 & \\
Based on Islamic principles & .814 & -.183 & & \\
Avoid Unauthorized Income & .806 & .224 & -.162 & \\
Customer Partner & .797 & -.115 & .223 & -.178 \\
Economic Development & .796 & .118 & & .144 \\
Avoid Unfair Transactions & .792 & -.183 & -.171 & \\
Family & .785 & .166 & -.269 & \\
Balanced Profit & .779 & .352 & .179 & .285 \\
Avoid Money Laundering & .778 & & -.293 & \\
Freedom & .766 & -.171 & -.165 & .202 \\
Social Responsibility Commitment & .761 & -.312 & .197 & -.133 \\
Do not conduct Haram Transactions & .752 & .164 & & \\
Customer as a Partner & .745 & .299 & & \\
Can be trusted & .742 & .231 & -.320 & -.361 \\
Investment for Rights & .738 & & .250 & -.150 \\
Successful Implementation of Principles & .734 & -.199 & -.288 & \\
Proportion of Profit Sharing & .728 & -.223 & .319 & \\
Balanced Risk & .714 & .303 & & .421 \\
No Interest on Deposits & .706 & -.374 & .177 & .153 \\
Profit Agreement & .702 & .412 & .123 & -.174 \\
No Loan Interest & .680 & -.376 & .262 & .204 \\
Not Differentiating Customers & .627 & & -.466 & .419 \\
Profit Sharing & .622 & .575 & .245 & \\
Harmonious interaction & .618 & .396 & .193 & -.121 \\
\hline
\end{tabular}

Source: Analyzed Data, 2018 
Based on Table 4 above, it explain the components 1 to 31 which represent the number of Islamic values in this study. The initial eigenvalues find 4 factors that exceed the total value 1 . This indicates that the 31 variables mentioned above will be grouped into 4 factors (latent constructs). The variance can be explained by factor 1 which is $18.138 / 31 \times 100 \%=58.51 \%$ and Factor 2 is $1.927 / 31 \times 100 \%=6.21 \%$. Furthermore, the variance that can be explained by Factor 3 is $1,296 / 31 \times 100 \%=4.18 \%$ and factor 4 is $1,058 / 31 \times 100 \%=3.41 \%$. The four factors will explain the variable of $58.51 \%+6.21 \%+4.18 \%+3.41 \%=$ $72.31 \%$.

After knowing that the maximum factor that can be formed is 4 , then determining the correlation of each independent variable will enter into factor 1 , factor 2, factor 3 or factor 4 . The way to look at the Component Matrix table as follows:

Table 5 Rotated Component Matrix ${ }^{a}$

\begin{tabular}{|c|c|c|c|c|}
\hline & \multicolumn{4}{|c|}{ Component } \\
\hline & 1 & 2 & 3 & 4 \\
\hline No Interest on Deposits & .787 & 154 & & .259 \\
\hline Islamic nuance & .755 & 136 & 156 & 282 \\
\hline Social Responsibility Commitment & .753 & .353 & 195 & .234 \\
\hline Proportion of Profit Sharing & .738 & 211 & 368 & \\
\hline Legal Benefits & .736 & 313 & .165 & 126 \\
\hline Customer Partner & 651 & 312 & .386 & 361 \\
\hline Based on Islamic principles & .646 & 391 & 395 & \\
\hline Investment for Rights & .617 & 284 & .443 & 223 \\
\hline Transactions are not speculated & 611 & 391 & 332 & \\
\hline Profit Sharing & .584 & 161 & .492 & .394 \\
\hline Balanced Profit & .134 & 854 & .151 & \\
\hline Profit Agreement & .356 & .744 & & 399 \\
\hline Harmonious interaction & 210 & .717 & 379 & \\
\hline Customer as a Partner & 209 & 690 & 265 & \\
\hline Balanced Risk & 288 & 634 & .338 & 225 \\
\hline Avoid Unauthorized Income & 298 & 631 & & .543 \\
\hline Risk Minimization & 265 & .526 & 434 & .440 \\
\hline Economic Development & .465 & .523 & .286 & .405 \\
\hline Do not conduct Haram Transactions & .443 & .522 & .247 & 375 \\
\hline Willingness in Covenant & 349 & .512 & .417 & 210 \\
\hline Can be trusted & .428 & 447 & 437 & 322 \\
\hline Accurate Information & .114 & .429 & .770 & 215 \\
\hline Clear contract & 391 & 340 & .692 & 194 \\
\hline Avoid Money Laundering & .522 & .350 & .597 & .150 \\
\hline Investment Guarantee & .329 & 269 & .580 & 424 \\
\hline Avoid Unfair Transactions & .544 & 201 & .559 & .332 \\
\hline Not Differentiating Customers & .496 & 194 & .546 & 341 \\
\hline
\end{tabular}




\begin{tabular}{|l|l|l|l|l|} 
Freedom & .168 & .169 & .259 & $\mathbf{. 8 1 4}$ \\
Family & .498 & .201 & .325 &. $\mathbf{5 3 9}$ \\
Successful Implementation of Principles & .239 & .431 & .455 & $\mathbf{. 5 2 3}$ \\
& .424 & .114 & .479 & $\mathbf{. 4 9 1}$ \\
\hline
\end{tabular}

Extraction Method: Principal Component Analysis.

Rotation Method: Varimax with Kaiser Normalization.

a. Rotation converged in 9 iterations.

Source: Analyzed Data, 2018

As the final step in determining the factor, you can see the following Component Transformation Matrix table:

Table 6 Component Transformation Matrix

\begin{tabular}{|c|r|r|r|r|}
\hline $\begin{array}{l}\text { Componen } \\
\mathrm{t}\end{array}$ & \multicolumn{1}{|c|}{1} & \multicolumn{1}{|c|}{2} & \multicolumn{1}{c|}{3} & \multicolumn{1}{c|}{4} \\
\hline 1 & .598 & .508 & .484 & .388 \\
2 & -.625 & .779 & -.040 & -.006 \\
3 & .496 & .366 & .530 & -.583 \\
4 & .074 & .029 & -.695 & .714 \\
\hline
\end{tabular}

Extraction Method: Principal Component Analysis.

Rotation Method: Varimax with Kaiser Normalization.

Source: Analyzed Data, 2018

Based on Table 6, it is known that the Factor 1 and Factor 3 have a strong correlation with the correlation value of Factor 1 of 0.598 and Factor 3 with a correlation value of 0.530 , while Factor 2 and Factor 4 have a strong correlation because they have a correlation of 0.779 for Factors 2 and equal to 0.714 for Factor 4 correlation. Thus, the four factors can express exactly the 31 independent variables.

\section{Discussion}

In the previous analysis, it is known that the factors formed from Islamic values based on the perspective of sharia bank customers in Makassar City are forming 4 factors. The factors formed can be seen more clearly in the following table. 
Table. 7 Exploration of Islamic values

\begin{tabular}{|c|c|c|c|}
\hline $\begin{array}{c}\text { FAKTOR } 1 \\
\text { (Product) }\end{array}$ & $\begin{array}{l}\text { FAKTOR } 2 \\
\text { (Assurance) }\end{array}$ & $\begin{array}{l}\text { FAKTOR } 3 \\
\text { (Reliablity) }\end{array}$ & $\begin{array}{c}\text { FAKTOR } 4 \\
\text { (Service) }\end{array}$ \\
\hline $\begin{array}{l}\text { No Loan Interest } \\
\text { No Interest on Deposits } \\
\text { Islamic nuance } \\
\text { Social Responsibility } \\
\text { Commitment } \\
\text { Proportion of Profit } \\
\text { Sharing } \\
\text { Legal Benefits } \\
\text { Customer Partner } \\
\text { Based on Islamic } \\
\text { principles } \\
\text { Investment for Rights } \\
\text { Non Speculation } \\
\text { Transactions }\end{array}$ & $\begin{array}{l}\text { Profit Sharing } \\
\text { Balanced Profit } \\
\text { Profit Agreement } \\
\text { Harmonious interaction } \\
\text { Customer as a Partner } \\
\text { Balanced Risk } \\
\text { Avoid Unauthorized } \\
\text { Income } \\
\text { Risk Minimization } \\
\text { Economic Development } \\
\text { Do not conduct Haram } \\
\text { Transactions } \\
\text { Willingness in Covenant }\end{array}$ & $\begin{array}{l}\text { Can be trusted } \\
\text { Accurate } \\
\text { Information } \\
\text { Clear contract } \\
\text { Avoid Money } \\
\text { Laundering } \\
\text { Investment } \\
\text { Guarantee } \\
\text { Avoid Unfair } \\
\text { Transactions }\end{array}$ & $\begin{array}{l}\text { Not Differentiating } \\
\text { Customers } \\
\text { Freedom } \\
\text { Family } \\
\text { Successful } \\
\text { Implementation of } \\
\text { Principles }\end{array}$ \\
\hline Amanah & Tabliq & Shidiq & Fathanah \\
\hline
\end{tabular}

Islamic values in Islamic banks are the basis of the establishment of Islamic banks in Indonesia. The role of these values keeps the operational pace of Islamic banks; this value also distinguishes them from conventional banking. South Sulawesi is the most developed province in Eastern Indonesia, is only on the $10^{\text {th }}$ rank or only $1.30 \%$ of its contribution in Islamic banking in Indonesia. Market share of Islamic banking in South Sulawesi only reached 3.47\% lower than South-East Sulawesi which reached $4.17 \%$ with only 19 office networks, while in South Sulawesi there were 68 Islamic bank office networks.

Widigdo et al. (2016) found differences in the implementation of Islamic values in banking operations in Indonesia and proved that the perception of bank employees about the implementation of Islamic values was higher than the perceptions of bank customers. Endraswati (2015) revealed that the inability of Islamic banks to implement Islamic values will cause customers to become distrustful and eliminate the company's potential to develop. This is reinforced by the research of Baderi (2016) who found that there are still Islamic banks that have not fully implemented Islamic values. The Financial Services Authority (OJK) in the 2015-2019 Indonesian sharia bank roadmap revealed one of the weaknesses in the development of Islamic banks is that their products and services have not met the expectations of customers.

The results of this study try to identify Islamic values applied by Islamic banks in Makassar City based on customer perceptions so that they can meet their expectations. This study found that there are 4 factors of Islamic values desired by customers in dealing with Islamic banks in the city of Makassar, namely Islamic products, Islamic compliance guarantees, Islamic reliability, and Islamic services. 


\section{a. Islamic Product}

Islamic products in Islamic banks are the identity of products offered by Islamic banking in Makassar. These products are a mandate for Islamic banks in carrying out their functions as intermediary financing. In the customer's perception, Islamic products are desirable and quite correlated in the application of Islamic values of 0.598 .

The existence of Islamic banks is due to the fatwa that bank interest is usury. Something that is forbidden by God the Almighty as explained in the Qur'an QS. Al-Qaeda / 2: 275 namely: "And Allah justifies selling and forbid usury".

This indicates that customer expectations regarding Islamic bank Islamic products, namely no element of interest, both in savings and loan products in the management of Islamic banks in Makassar City. Islamic bank customers do not want Islamic banks to use the usury system.

Sharia bank products are a combination of banking products and Islamic foundations, and refer to applicable laws. In addition, it is undeniable that all Islamic bank products have Islamic nuances, both in naming their products and in binding contracts. In deposits of Islamic banks known as al-Wadi'ah and mudharabah. On the loan aspect, the terms syirkah (musyarakah) and mudharabah are used. Islamic banks also prove that in addition to being based on sharia principles, banks also have commitments in Corporate Social Responsibility/CSR, using profit sharing proportions in savings and investment, generating legitimate profits, becoming partners for customers, and transactions that are not based on speculation.

Islamic products Islamic banks are the main business of Islamic banking offered to the national banking market and can satisfy the needs and desires of customers. This factor can be a trust for Islamic banks.

\section{b. Guaranteed Sharia Compliance}

Sharia compliance guarantees are the bank's efforts in promoting or conveying to customers that the bank guarantees the willingness or sincerity of the customer in dealing with the bank. This guarantee of compliance is a tabliq for Islamic banks in applying Islamic values. Customers' perceptions of collateral have a high correlation in the application of Islamic values in sharia banking at 0.779 , namely: (a) there is a guarantee of profit sharing benefits; (b) guarantee of a balanced profit; (c) an agreement in the desired profit; (d) there is a guarantee of harmonious interaction between Islamic banks and their customers; (e) the existence of customer guarantees as work partners; (f) guaranteeing that the risks occur equally; (g) guaranteeing avoiding unauthorized income; (h) guarantee to minimize the risks that will occur; (i) guaranteeing the economic development of customers; (j) guarantee not to make legal transactions; $(\mathrm{k})$ guarantee that all parties have compliance in the contract. This factor contains variables of Islamic values which are "Islamic 
Performance" of Islamic banks which are the work of Islamic banks. This factor can be Tabliqh for Islamic banks.

\section{c. Islamic Reliability}

Factor 3 is Islamic reliability which is the honesty of the bank in providing information and in transactions with its customers. In Islamic Corporate Governance, this is synonymous with shidiq. This Islamic reliability is the customer's desire for Islamic banks with a correlation of 0.530 in applying Islamic values, namely: (a) can be trusted; (b) provide easy information that is accurate; (c) binding of clear contract; (d) avoid money laundering; (e) investments made are reliable; (f) avoid unfair transactions. This factor contains variables of Islamic values that are "Islamic reliability or guarantee" which is a good application of the functions of Islamic banks, without failures, in accordance with the wishes of customers. This factor is identical to Shidiq for Islamic banks.

\section{d. Islamic Services}

Islamic services are a form of Islamic bank creativity in providing services to customers. Islamic service is a fathanah concept in Islamic banks with a high correlation of 0.714 in applying Islamic values, namely through: (a) not distinguishing customers in service; (b) giving freedom in contract arrangements; (c) serving more than just cooperating or ordinary professional relationships; (d) Islamic banking services successfully implement sharia principles. This factor contains variables of Islamic values which are "Islamic services" which are the process of fulfilling customer needs through direct Islamic bank activities and providing everything needed by sharia bank customers. This factor is synonymous with Fathanah for Islamic banks.

\section{Conclusion}

The function of the Islamic Bank is amar ma'ruf nahi munkar based on the Qur'an and hadith. Article 2 of Law No. 21 of 2008 clearly explains that the business activities of Islamic banks are based on Islamic values. This study found that the expectations of sharia bank customers consisted of 4 factors, namely: Amanah in the Product, Tablig in its Guarantee, Sidiq on the reliability of the bank and Fathanah on the Service. These four variables provide high soybeans in the application of Islamic values to Islamic banks in Makassar.

\section{Limitation and Suggestions}

This study also has a weakness, which is only limited in exploring Islamic values and has not been followed up with confirmation of the four factors formed by the analysis of Confirmatory Factor Analysis (CFA). 
However, this study also found answers to Islamic values desired by customers in Islamic banking activities. This research is also able to form Islamic Corporate Governance indicators as a respond to research challenges suggested by Endraswati Wisdom about the Initial Concept of Islamic Corporate Governance: Future Research Opportunities, that Islamic Corporate Governance is also implemented in Islamic banks through amanah in their products, tabliqin providing guarantees to customers, shiddiq which is reliability like sharia, and fathanah in serving customers in every banking transaction.

\section{REFERENCES}

Bank Indonesia (2008). Undang-Undang Republik Indonesia Nomor 21 Tahun 2008 Tentang Perbankan Syariah

Cooper, Donald R. and Pemela S. Schindler. (2003). Business Research Methods, International Edition. New York: McGraw-Hill Companies, Inc.

Daradjat, Zakiah (1984). Kesehatan Mental Peranannya Dalam Pendidikan dan Pengajarannya. Jakarta: Gunung Agung

Dusuki, Asyraf Wajdi (2008) "Understanding the objectives of Islamic banking: a survey of stakeholders' perspectives", International Journal of Islamic and Middle Eastern Finance and Management, 1 (2),132148, https:/ / doi.org/10.1108/17538390810880982

Hair, J. F., Black, W. C., Babin, B. J., \& Anderson, R. E. (2012). Multivariate Data Analysis (Seventh Edition ed.). New Jersey: John Wiley \& Sons.

Jundiani (2009). Pengaturan Hukum Perbankan Syari'ah di Indonesia. Malang: UIN Malang Press.

Jundiani (2009). Pengaturan Hukum Perbankan Syariah di Indonesia. UIN Maliki Press, Malang

Latif, Abdul (2014). Nilai-Nilai Dasar dalam Membangun Ekonomi Islam. Diktum: Jurnal Syariah dan Hukum.12 (2).

Lee, K. H., \& Ullah, S. (2011). Customers' Attitude Toward Islamic Banking In Pakistan. International Journal of Islamic and Middle Eastern Finance and Management, 4(2),

131-145. http://dx.doi.org/10.1108/17538391111144524

Lubis, Muhammad Arif Fadhillah (2015). Prinsip Dasar Muamalah Keuangan Syariah (Maliyah). Wahana Islamika: Jurnal Studi Keislaman. 1 (1).

M. Arifin (1993).Ilmu Pendidikan Islam. Jakarta : Bumi Aksara.

Mas'ud, Fuad (2004).Survai Diagnosis Organisasional. Semarang: Badan Penerbit Universitas Diponegoro.

Misbach, Irwan. 2013. Bank Syariah: Kualitas Layanan, Kepuasan dan Kepercayaan. Makassar: Alauddin University Press.

Osman, I., Ali, H., Zainuddin, A., \& Rashid, W. E. W. (2009). Customer satisfaction in Malaysian Islamic Banking. International Journal of Economic and Finance, 1(1), 197-202.

Otorisasi Jasa Keuangan (2017). Laporan Perkembangan Keuangan Syariah 2015. Jakarta: OJK 
Otoritas Jasa Keuangan (2017). Snapshot of Indonesia Islamic Banking Development 2017 https://www.ojk.go.id/en/berita-dankegiatan/publikasi/Documents/ Pages/Snapshot-of-Indonesia-IslamicBanking-Development-2017/ Indonesia\%20Islamic\%20Banking\%20Snapshot\%202017\%20(V3).pdf

Rifqi, Muhammad (2008). Akuntansi Keuangan Syariah. Yogyakarta: P3EI Press.

Shafie, S., Azmi, W. N. W., \& Haron, S. (2004). Adopting And Measuring Customer Service Quality In Islamic Banks: A Case Study Of Bank Islam Malaysia Berhad. Journal of Muamalat and Islamic Finance Research, 1(1), 112

Supranto, J, (2004).Analisis Multivariat: Arti dan Interpretasi. Jakarta, PT. Rineka Cipta.

Widarjono, Agus (2010). Analisis Statistika Multivariat Terapan. Edisi Pertama. Yogyakarta: UPP STIM YKPN. 